\title{
Synthesis of novel salicylic acid-pyrrolone conjugates and investigation of their cytotoxic and genotoxic effects in Allium cepa root tip cells
}

\author{
Mehmet Gümüş ${ }^{1, *}$, Selin Can $\oplus^{2}$, H. Erhan Eroğlu $\oplus^{2, \dagger}$ \\ and İrfan Koca $\oplus^{3}$ \\ ${ }^{1}$ Akdağmadeni Health College, Yozgat Bozok University, Yozgat, Türkiye \\ ${ }^{2}$ Department of Biology, Faculty of Art \& Sciences, Yozgat Bozok University, Yozgat, Türkiye \\ ${ }^{3}$ Department of Chemistry, Faculty of Art \& Sciences, Yozgat Bozok University, Yozgat, Türkiye
}

(Received July 5, 2021; Revised August 6, 2021; Accepted August 13, 2021)

\begin{abstract}
In the 20th century, many new drugs have been designed and synthesized to be used for therapeutic purposes. In these syntheses, especially the salicylic acid group is included in the structure of many drugs. The salicylic acid molecule is the starting material of aspirin and is a structurally important compound. There are many commercial products on the market that are synthesized from salicylic acid or contain salicylic acid group. In this study, the synthesis of salicylic acid-pyrrolone hybrid compounds was carried out from the reactions of furan-3-one compounds with 4-aminosalicylic acid and 5-aminosalicylic acid reagents. The synthesis reactions were achieved in three steps and in these synthesis, biologically active pyrrolone and salicylic acid groups were integrated. The characterizations of these compounds that were purified by column chromatography and crystallization method were made by FTIR, NMR and HRMS techniques. The cytotoxic and genotoxic potentials of the novel compounds (7a-e) were evaluated at five different concentrations $(6.25,12.5,25,50$ and $100 \mu \mathrm{M})$ using the Allium test system. As a result of cytogenetic analysis, it was determined that high concentrations of some hybrid compounds significantly reduced the number of divisions of $A$. cepa cells (cytotoxicity in $\mathbf{7 a}$ and $\mathbf{7 c}$ ) and caused chromosomal abnormalities in dividing cells (genotoxicity in $\mathbf{7 a}, \mathbf{7 c}, \mathbf{7 e}$, and especially $\mathbf{7 d}$ ).
\end{abstract}

Keywords: Salicylic acid; pyrrolone; hybrid compound; diastereotopic proton; chromosome; mitotic index. (2021 ACG Publication. All right reserved.

\section{Introduction}

Salicylic acid was synthesized from salicin by Piria in 1835. Later, Benoit carried out the reaction of nitric acid and anthranilic acid to obtain salicylic acid. The synthesis of salicylic acid, which is used today, was developed by Herman Kolbe in 1860. Salicylic acid has started to be used as an antiseptic in surgeries instead of phenol, which harms human health. ${ }^{1}$ Acetyl salicylic acid was synthesized in 1897 by Felix Hoffmann, who worked at Bayer, and it was named Aspirin in 1899.

\footnotetext{
* Corresponding authors: E-Mail: mehmet.gumus@bozok.edu.tr, Phone: + 90 3543141415; Fax: + 90 3543141416; herhan.eroglu@ bozok.edu.tr, Phone: + 90 3542421021; Fax: + 903542421022.
}

The article was published by ACG Publications 
Gümüş et al., Org. Commun. (2021) 14:3 280-293

Although it is generally used as a pain reliever and antipyretic, it is also known to have beneficial effects against rheumatism and cancer. ${ }^{2}$

Synthesis and pharmaceutical studies on salicylic acid compounds have enabled the production of many commercial drugs. Mesalazine, one of these compounds, also known as 5-aminosalicylic acid (5-ASA) or mesalamine, is a drug containing salicylic acid group, used in the treatment of many inflammatory bowel diseases, especially ulcerative colitis. Salicylic acid compound is involved in the chemical structure of many antimicrobial, neuroprotective, anti-cancer and anti-inflammatory agents. ${ }^{3}$ One of these drugs is Sulfasalazine (salazosulfapyridine). Sulfasalazine was produced in 1938 by Swedish professor Nanna Svartz. In the late 1970s, sulfasalazine began to be used as an anti-rheumatic drug when McConkey et al. reported its beneficial effect in rheumatoid arthritis with fewer side effects than gold and penicillamine. ${ }^{4-5}$ In a study conducted in 2017, the anticancer activity properties of the sulfasalazine compound in liver cancer cell lines were investigated and promising results were obtained in terms of chemotherapy. ${ }^{6}$ After it was understood that 5-ASA is the catabolism product of sulfasalazine, many 5-ASA-based drugs have been developed to improve their pharmacokinetic and pharmacodynamic compatibility. ${ }^{7}$ In addition, when the chemical structures of Balsalazid and Olsalazine compounds used as drugs are examined, the presence of salicylic acid groups attracts attention. Some of the salicylic acid derivative drugs are shown in Figure 1. ${ }^{8-9}$

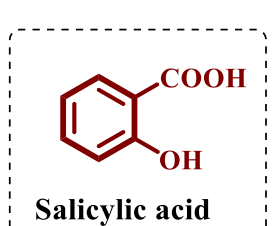
(Acetyl salicylic acid)

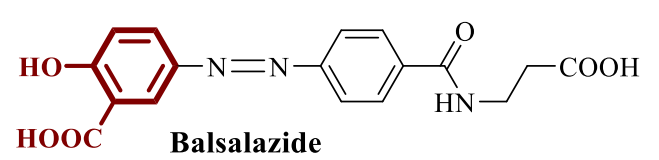

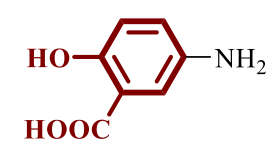

5-aminosalicylic acid (5-ASA)

HOO

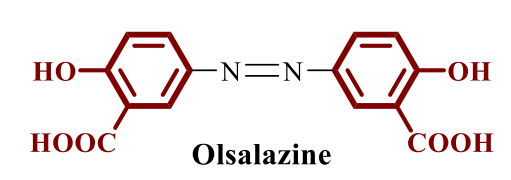

Figure 1. Some drugs containing salicylic acid group

Pyrrole is an aromatic heterocyclic compound with a five-membered ring consisting of four carbons and one nitrogen atom. Pyrrole is a liquid with a boiling point of $131{ }^{\circ} \mathrm{C}$, with a distinctive and unpleasant odour. Due to the resonance, its basic property is very weakened. The first isolation was made from hard coal tar. Later, the structural formula of pyrrole obtained from the pyrolysis of bone fat was determined by A. Von Baeyer in $1870 .{ }^{10}$ Pyrrole compounds, which have an important place in the fields of chemistry, pharmacy and industry, show various biological activities such as antiviral, antiinflammatory, antibacterial and anti-tumor. ${ }^{11-12}$

The quintuple ring system of the pyrrole core can be derivatized using various substituents. As a result of derivatization of this core with the carbonyl group, pyrrolone compounds are obtained. These compounds are important chiral molecules used in the preparation of various bioactive molecules. The use of these compounds in intermediate steps as chiral molecules is often preferred for determining the absolute configuration. Pyrrolone compounds are preferred in cycloadditions, acyliminium ion chemistry and allyl substitution reactions due to their multifunctional nature. ${ }^{13}$ The pyrrolone skeleton is recognized as an important structure with various pharmacological activities, including antimicrobial, anti-inflammatory, analgesic, antiviral and antitumor activities. ${ }^{14-17}$ Pyrrolone compounds are important structures of choice in the development of drugs for the treatment of many infectious diseases. TDR32750 molecule developed against Plasmodium falciparum K1 is an important pyrrolone compound with antimalarial properties (Figure 2). ${ }^{18-19}$ Some pyrrolone hybrid structures have also been designed and synthesized as HIV-1 protease inhibitors. ${ }^{20}$ In addition, the antiviral effects of substituted pyrrolone derivatives designed with the structure-activity relationship against $\mathrm{HCV}$ were examined and new pyrrolone derivatives were determined with EC50 values in the low micromolar range (Figure 2). ${ }^{21}$ 
Synthesis of novel hybrid compounds and their cytotoxic and genotoxic effetcs

A limited number of methods are known for the synthesis of pyrrolone derivatives. Multicomponent reactions ${ }^{22}$, multi-step reactions ${ }^{18}$, copper-catalyzed cyclization of enamino amides ${ }^{23}$, self-condensation of enaminones ${ }^{24}, \mathrm{Pt}$ and Au-catalyzed intramolecular amination of amino ynons ${ }^{25-26}$, NIS-catalyzed cyclization of diynones ${ }^{27}$ are important applications for pyrrolone synthesis.<smiles>CCOC(=O)C1=C(C)N/C(=C/c2cc(C)n(-c3ccccc3C(F)(F)F)c2C)C1=O</smiles>

TDR32750 (antimalarial)

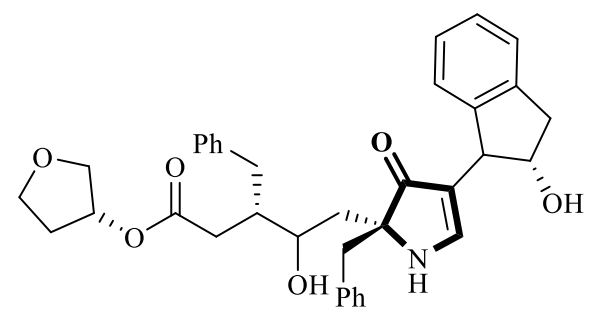

HIV-1 protease inhibitor

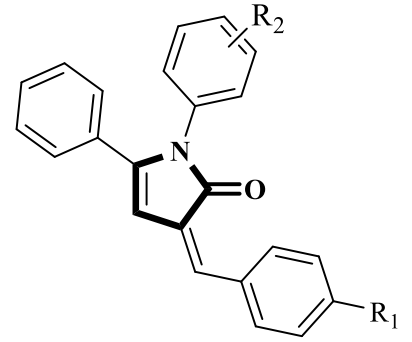

antiviral agents

Figure 2. Biologically active some pyrrolone compounds

The Allium test is used to determine the cytotoxic and/or genotoxic effects of various substances. Higher plants are suitable for cytological analysis due to the size of their chromosomes. ${ }^{28}$ These plants are preferred in genotoxicity tests because their genetic material is preserved. ${ }^{29}$ The Allium test is an easy to use and inexpensive test that correlates particularly well with mammalian testing systems.$^{30}$ The results of the Allium test may indicate the presence of certain cytotoxic/genotoxic or mutagenic substances that represent direct or indirect risks to living organisms. In Allium test, it is generally explained growth retardation by cytotoxicity and basic chromosome aberrations by genotoxicity. ${ }^{31}$ Mitotic index (MI), mitotic abnormalities and chromosome aberrations (CA) can be determined with the concentrations and different application times determined by the Allium root growth inhibition test. The cytotoxicity level of a chemical can be determined by a decrease or increase in MI. While it can be concluded that the growth and development of the plant is inhibited by the effect of the exogenous substance exposed with the decrease observed in MI, the increase observed in MI may mean irregular cell divisions and a tumorous tissue..$^{29,32} \mathrm{CA}$ is changes in chromosome structure or chromosome number as a result of exposure of Allium cells to physical or chemical substances. ${ }^{33}$

In this study, novel salicylic acid-pyrrolone hybrid compounds were synthesized. By using 4aminosalicylic acid and 5-aminosalicylic acid reagents, the syntheses of the target compounds from furan-3-one compounds were made. The newly synthesized compounds (7a-e) were purified by crystallization and column chromatography methods, and their structures were characterized by FTIR, ${ }^{1} \mathrm{H}$ NMR, ${ }^{13} \mathrm{C}$ NMR and HRMS techniques. The potential cytotoxic and genotoxic effects of hybrid compounds (7a-e) containing biologically active nuclei were investigated at 6.25, 12.5, 25, 50 and 100 $\mu \mathrm{M}$ concentrations using the Allium test system.

\section{Experimental}

\subsection{Chemical Material and Apparatus}

The chemicals and all solvents used in this work were purchased from the supplier and were used without purification. All reactions were monitored by TLC (Silica gel, aluminum sheets 60 F254, Merck), which were visualized under UV light. and column chromatography was carried out on silica gel 60N (spherical, neutral). Melting points (not corrected) were recorded in open capillary tubes on Electrothermal 9200 digital melting point apparatus (Yozgat Bozok University). Fourier transform infrared spectra were recorded in the spectral range of $4000-400 \mathrm{~cm}^{-1}$ on a Perkin Elmer Spectrum Two Model FT-IR spectrophotometer using ATR method with a resolution of $4 \mathrm{~cm}^{-1}$ at room temperature (Yozgat Bozok University). HRMS analyses spectra were obtained using a Agilent Technologies 6224 TOF LC/MS (Bilkent University-UNAM). ${ }^{1} \mathrm{H}$ NMR and ${ }^{13} \mathrm{C}$ NMR spectra were recorded on a Bruker Ultrashield NMR spectrometer using DMSO- $d_{6}$ as solvent and TMS as an internal reference (Erciyes University, TAUM Laboratory. Chemical shifts are expressed in $\delta \mathrm{ppm}$ and coupling constants $(J$ 
Gümüş et al., Org. Commun. (2021) 14:3 280-293

values) are reported in hertz. Multiplicities are expressed as s (singlet), $d$ (doublet), $t$ (triplet), q (quartet), $\mathrm{m}$ (multiplet) and br (broad).

\subsection{Chemistry}

2.2.1. General Procedure for the Synthesis of Methyl(2E)-[4-(4-methoxybenzoyl)-5-(4-methoxyphenyl)3-oxofuran-2(3H)-ylidene]acetate (3a)

A mixture of 1,3-bis(4-methoxyphenyl)propane-1,3-dione 1a (2.84 g, $10.0 \mathrm{mmol})$ and oxalyl chloride $2(1.27 \mathrm{~g}, 10.0 \mathrm{mmol})$ in dry benzene $(60 \mathrm{ml})$ was heated at $50^{\circ} \mathrm{C}$ for 1 hour in a $250 \mathrm{~mL}$ reaction flask until the reaction was completed (followed by TLC). After benzene was removed under reduced pressure, the residue was treated with diethylether and the substance precipitated was filtered off and used directly without further purification for the next step reaction. ${ }^{34}$

\subsubsection{General Procedure for the Synthesis of Ethyl (5Z)-5-(2-methoxy-2-oxo-ethylidene-2-(4-}

methoxyphenyl)-4-oxo-4,5-dihydrofuran-3-carboxylate ( $3 \boldsymbol{b}$ )

To solution of ethyl 3-(4-methoxyphenyl)-3-oxopropanoate $\mathbf{1 b}(3.00 \mathrm{~g}, 13.50 \mathrm{mmol})$ in $60 \mathrm{~mL}$ $n$-hexane : diethylether mixture (1:2), oxalyl chloride $2(1.71 \mathrm{~g}, 13.50 \mathrm{mmol})$ was added dropwise. It was kept in a closed dark place for one day. At the end of this period, the yellow colored substance precipitated in reaction flask was filtered off and used directly without further purification for the next step reaction. ${ }^{35}$

\subsubsection{General Procedure for the Synthesis of Furan-3-one Derivatives (5)}

A mixture of 2,3-dihydro-furan-2.3-dione $3(10.0 \mathrm{mmol})$ and Wittig reagent $4(10.0 \mathrm{mmol})$ in dry benzene $(50 \mathrm{~mL})$ was refluxed for $30 \mathrm{~min}$. After the solvent was removed under reduced pressure, the oily residue was treated with cold methanol $\left(20 \mathrm{~mL}, 0-5^{\circ} \mathrm{C}\right)$ or petroleum ether to obtain the corresponding crude product and then was purified by recrystallization from methanol or 2-propanol and was dried over $\mathrm{P}_{2} \mathrm{O}_{5}$ in a vacuum desiccator. ${ }^{36-37}$

\subsubsection{General Procedure for Synthesis of Novel Salicylic Acid-Pyrrole Hybrid Compounds (7a-e)}

A mixture of furan-3-one $5(10.0 \mathrm{mmol})$ and salicylic acid derivative $\mathbf{6}(10.0 \mathrm{mmol})$ in methanol $(30 \mathrm{~mL})$ was refluxed in the presence of catalytic amount of pyridine for 24 hours. The reaction was followed by TLC. After the solvent was removed under reduced pressure, the oily residue was treated with diethylether. The crude product was filtered off and purified by recrystallization or column chromatography methods. $n$-butanol was used in recrystallization processes and chloroform:methanol (10:1) was used as eluent in column chromatography processes (Yields: 74-83\%).

2-hydroxy-5-(2-hydroxy-2-(2-methoxy-2-oxoethyl)-4-(4-methoxybenzoyl)-5-(4-methoxy phenyl)-3-oxo2,3-dihydro-1H-pyrrol-1-yl)benzoic acid (7a): Color: light yellow, Yield 74\%, FTIR (ATR, cm ${ }^{-1}$ ): 3270 (br, OH), 3071-2844 (aromatic and alifatic CH), 1728 (CO, ester), 1704 (CO, acid), 1698 (CO, benzoyl), 1679 (CO, pyrrole), 1598-1444 (C=C), $1251\left(\mathrm{O}_{-} \mathrm{CH}_{3}\right) .{ }^{1} \mathrm{H}$ NMR $\left(400 \mathrm{MHz}, \mathrm{DMSO}-d_{6}\right): 11.36$ (br s, $1 \mathrm{H}$, $\mathrm{COOH}), 7.80\left(\mathrm{~d}\right.$, the part A of AA'BB' system, $\left.{ }^{3} \mathrm{~J}_{\mathrm{H}-\mathrm{H}}=8.7 \mathrm{~Hz}, 2 \mathrm{H}, \mathrm{H}-1\right) ; 7.55(\mathrm{~s}, 1 \mathrm{H}, \mathrm{Ar}-\mathrm{H}), 7.11(\mathrm{~d}, 1 \mathrm{H}$, $\left.{ }^{3} J_{\mathrm{H}-\mathrm{H}}=7.6 \mathrm{~Hz}, \mathrm{Ar}-\mathrm{H}\right), 7.04\left(\mathrm{~d}\right.$, the part A of AA'BB' system, $\left.{ }^{3} J_{\mathrm{H}-\mathrm{H}}=8.6 \mathrm{~Hz}, 2 \mathrm{H}, \mathrm{H}-3\right) ; 6.96$ (d, the part B of AA'BB' system, $\left.{ }^{3} J_{\mathrm{H}-\mathrm{H}}=8.6 \mathrm{~Hz}, 2 \mathrm{H}, \mathrm{H}-4\right) ; 6.88\left(\mathrm{~d}, 1 \mathrm{H},{ }^{3} J_{\mathrm{H}-\mathrm{H}}=8.8 \mathrm{~Hz}, \mathrm{Ar}-\mathrm{H}\right), 6.83(\mathrm{~d}$, the part B of AA'BB' system, $\left.{ }^{3} J_{\mathrm{H}-\mathrm{H}}=8.7 \mathrm{~Hz}, 2 \mathrm{H}, \mathrm{H}-2\right), 3.83 ; 3.69 ; 3.57(3 \mathrm{~s}, 9 \mathrm{H}, 3 \mathrm{MeO}) ; 3.02$ (the part A of the AB system, d, $\left.1 \mathrm{H}, J_{\mathrm{gem}}=16.3, \mathrm{CH}_{2} \mathrm{COOMe}\right), 2.55-\mathrm{DMSO}-d_{6}($ Part $\mathrm{B}$ of the AB system, d, $1 \mathrm{H}$, $\left.\mathrm{CH}_{2} \mathrm{COOMe}\right) .{ }^{13} \mathrm{C}$ NMR (101 MHz, DMSO) $\delta 194.4$ (CO, ketone), $188.3(\mathrm{C}=\mathrm{O}$, benzoyl), $177.1(\mathrm{C}=\mathrm{O}$, ester), 171.3 (C=O, acid), 169.2, 163.1, 161.2, 160.4, 136.0, 132.1, 131.2, 130.4, 128.0, 122.0, 118.3, 114.2, 113.8, 113.7, 112.6, $111.4(\mathrm{C}=\mathrm{C}), 89.5(\mathrm{~N}-\mathrm{C}-\mathrm{OH}), 55.9\left(\mathrm{OCH}_{3}\right), 55.7\left(\mathrm{OCH}_{3}\right), 52.2\left(\mathrm{OCH}_{3}\right), 40.1$ $\left(\mathrm{CH}_{2}\right)$. HRMS: $m / z(\mathrm{M}+\mathrm{H})$ calcd. for $\mathrm{C}_{29} \mathrm{H}_{25} \mathrm{NO}_{10}$ : 548.1551; found: 548.1547. 
Synthesis of novel hybrid compounds and their cytotoxic and genotoxic effetcs

5-(2-(2-ethoxy-2-oxoethyl)-2-hydroxy-4-(4-methoxybenzoyl)-5-(4-methoxyphenyl)-3-oxo-2,3-dihydro1H-pyrrol-1-yl)-2-hydroxybenzoic acid (7b): Color: light yellow, Yield 80\%, FTIR (ATR, $\mathrm{cm}^{-1}$ ): 3309 (br, OH), 3082-2844 (aromatic and alifatic $\mathrm{CH}$ ), 1722 (CO, ester), 1701 (CO, acid), 1683 (CO, benzoyl), 1653 (CO, pyrrole), 1598-1445 (C=C), $1253\left(\mathrm{O}^{\left.-\mathrm{CH}_{3}\right) .}{ }^{1} \mathrm{H}\right.$ NMR (400MHz, DMSO- $\left.d_{6}\right): 11.54$ (br s, $1 \mathrm{H}$, $\mathrm{COOH}), 7.81-6.82(\mathrm{~m}, 11 \mathrm{H}, \mathrm{Ar}-\mathrm{H}) ; 4.04\left(\mathrm{q}, 2 \mathrm{H},{ }^{3} J_{\mathrm{H}-\mathrm{H}}=6.2 \mathrm{~Hz}, \mathrm{OCH}_{2} \mathrm{CH}_{3}\right), 3.82 ; 3.69(2 \mathrm{~s}, 6 \mathrm{H}, 2 \mathrm{MeO})$; 3.00 (the part $\mathrm{A}$ of the $\mathrm{AB}$ system, $\mathrm{d}, 1 \mathrm{H}, J_{\mathrm{gem}}=16.4, \mathrm{CH}_{2} \mathrm{COOMe}$ ), 2.53-DMSO- $d_{6}$ (the part $\mathrm{B}$ of the $\mathrm{AB}$ system, d, $\left.1 \mathrm{H}, \mathrm{CH}_{2} \mathrm{COOMe}\right), 1.11\left(\mathrm{t}, 2 \mathrm{H},{ }^{3}{ }_{\mathrm{H}-\mathrm{H}}=6.2 \mathrm{~Hz}, \mathrm{OCH}_{2} \mathrm{CH}_{3}\right) .{ }^{13} \mathrm{C} \mathrm{NMR}(101 \mathrm{MHz}, \mathrm{DMSO})$ $\delta$ 194.4 (CO, ketone), $188.2(\mathrm{C}=\mathrm{O}$, benzoyl), $177.1(\mathrm{C}=\mathrm{O}$, ester $), 171.4(\mathrm{C}=\mathrm{O}$, acid $), 168.6,163.1,161.2$, $160.4,136.0,132.1,132.1,131.3,130.4,128.0,121.9,118.3,114.2,113.8,113.6,111.4(\mathrm{C}=\mathrm{C}), 89.5$ (N-C-OH), $61.0\left(\mathrm{OCH}_{2} \mathrm{CH}_{3}\right), 55.9\left(\mathrm{OCH}_{3}\right), 55.7\left(\mathrm{OCH}_{3}\right)$, in DMSO-d $\left(\mathrm{CH}_{2} \mathrm{COOEt}\right), 14.3\left(\mathrm{OCH}_{2} \underline{\mathrm{CH}}_{3}\right)$. HRMS: $m / z(\mathrm{M}+\mathrm{H})$ calcd. for $\mathrm{C}_{30} \mathrm{H}_{27} \mathrm{NO}_{10}$ : 562.1708; found: 562.1708 .

2-hydroxy-4-(2-hydroxy-2-(2-methoxy-2-oxoethyl)-4-(4-methoxybenzoyl)-5-(4-methoxy phenyl)-3-oxo2,3-dihydro-1 H-pyrrol-1-yl)benzoic acid (7c): Color: light yellow, Yield 75\%, FTIR (ATR, $\left.\mathrm{cm}^{-1}\right): 3274$ (br, OH), 3012-2840 (aromatic and alifatic $\mathrm{CH}$ ), 1736 (CO, ester), 1726 (CO, acid), 1686 (CO, benzoyl), 1673 (CO, pyrrole), 1602-1458 (C=C), $1255\left(\mathrm{O}_{-} \mathrm{CH}_{3}\right) .{ }^{1} \mathrm{H}$ NMR (400MHz, DMSO- $\left.d_{6}\right): 7.83-6.38(\mathrm{~m}$, $11 \mathrm{H}, \mathrm{Ar}-\mathrm{H}) ; 3.82 ; 3.70 ; 3.53\left(3 \mathrm{~s}, 9 \mathrm{H}, 3 \mathrm{MeO}\right.$ ); 3.05 (the part A of the AB system, d, $1 \mathrm{H}, J_{\mathrm{gem}}=16.4$, $\mathrm{CH}_{2} \mathrm{COOMe}$ ), 2.63 (the part B of the $\mathrm{AB}$ system, d, $\left.1 \mathrm{H}, J_{\text {gem }}=16.5, \mathrm{CH}_{2} \mathrm{COOMe}\right) .{ }^{13} \mathrm{C} \mathrm{NMR}(101 \mathrm{MHz}$, DMSO- $\left.d_{6}\right) \delta 194.6$ (CO, ketone), $188.4(\mathrm{C}=\mathrm{O}$, benzoyl), $176.1(\mathrm{C}=\mathrm{O}$, ester), $171.5(\mathrm{C}=\mathrm{O}$, acid), 169.0, 163.2, 162.2, 161.4, 142.4, 138.7, 132.1, 132.0, 131.1, 130.9, 122.1, 118.1, 115.9, 114.3, 113.8, 112.3 $(\mathrm{C}=\mathrm{C}), 89.7(\mathrm{~N}-\mathrm{C}-\mathrm{OH}), 55.9\left(\mathrm{OCH}_{3}\right), 55.7\left(\mathrm{OCH}_{3}\right), 52.2\left(\mathrm{COOCH}_{3}\right), 40.2\left(\mathrm{CH}_{2} \mathrm{COOMe}\right)$. HRMS: $\mathrm{m} / \mathrm{z}$ $(\mathrm{M}+\mathrm{H})$ calcd. for $\mathrm{C}_{29} \mathrm{H}_{25} \mathrm{NO}_{10}$ : 548.1551; found: 548.1533 .

4-(2-(2-ethoxy-2-oxoethyl)-2-hydroxy-4-(4-methoxybenzoyl)-5-(4-methoxyphenyl)-3-oxo-2,3-dihydro1H-pyrrol-1-yl)-2-hydroxybenzoic acid (7d): Color: light yellow, Yield 83\%, FTIR (ATR, $\left.\mathrm{cm}^{-1}\right)$ : 3345 (br, OH), 3071-2841 (aromatic and alifatic $\mathrm{CH}), 1721,1682(\mathrm{CO}), 1598-1453(\mathrm{C}=\mathrm{C}), 1250\left(\mathrm{O}-\mathrm{CH}_{3}\right)$. ${ }^{1} \mathrm{H}$ NMR $\left(400 \mathrm{MHz}, \mathrm{DMSO}-d_{6}\right): \delta 11.34(\mathrm{br} \mathrm{s}, 1 \mathrm{H}, \mathrm{COOH}), 7.84\left(\mathrm{~d}\right.$, the part A of AA'BB' system, ${ }^{3} J_{\mathrm{H}-}$ $\left.{ }_{\mathrm{H}}=8.6 \mathrm{~Hz}, 2 \mathrm{H}, \mathrm{H}_{\mathrm{a}}\right), 7.67\left(\mathrm{~d}\right.$, the part A of AA'BB' system, $\left.{ }^{3} J_{\mathrm{H}-\mathrm{H}}=8.5 \mathrm{~Hz}, 2 \mathrm{H}, \mathrm{H}_{\mathrm{c}}\right), 7.08(\mathrm{~d}$, the part B of AA'BB' system, $\left.{ }^{3} J_{\mathrm{H}-\mathrm{H}}=8.5 \mathrm{~Hz}, 2 \mathrm{H}, \mathrm{H}_{\mathrm{d}}\right), 6.97\left(\mathrm{~d}\right.$, the part B of AA'BB' system, $\left.{ }^{3} J_{\mathrm{H}-\mathrm{H}}=8.5 \mathrm{~Hz}, 2 \mathrm{H}, \mathrm{H}_{\mathrm{b}}\right)$, $6.86\left(\mathrm{~d}, 2 \mathrm{H}, \mathrm{Ar}-\mathrm{H}, \mathrm{H}_{\mathrm{e}}\right.$ and $\left.\mathrm{OH}\right), 6.63\left(\mathrm{~s}, 1 \mathrm{H}, \mathrm{Ar}-\mathrm{H}, \mathrm{H}_{\mathrm{g}}\right), 6.54\left(\mathrm{~d},{ }^{3} \mathrm{~J}_{\mathrm{H}-\mathrm{H}}=8.5 \mathrm{~Hz}, 1 \mathrm{H}, \mathrm{Ar}-\mathrm{H}, \mathrm{H}_{\mathrm{f}}\right), 4.00(\mathrm{q}$, $2 \mathrm{H},{ }^{3} J_{\mathrm{H}-\mathrm{H}}=5.8 \mathrm{~Hz}, \mathrm{OCH}_{2} \mathrm{CH}_{3}$ ), 3.06 (the part A of the AB system, d, $1 \mathrm{H}, J_{\mathrm{gem}}=16.4, \underline{\mathrm{CH}}_{2} \mathrm{COOMe}$ ), 2.64 (the part $\mathrm{B}$ of the $\mathrm{AB}$ system, d, $\left.1 \mathrm{H}, J_{\mathrm{gem}}=16.4, \mathrm{CH}_{2} \mathrm{COOMe}\right), 1.08\left(\mathrm{t}, 3 \mathrm{H},{ }^{3} J_{\mathrm{H}-\mathrm{H}}=7.0 \mathrm{~Hz}, \mathrm{OCH}_{2} \mathrm{CH}_{3}\right)$. ${ }^{13} \mathrm{C}$ NMR (101 MHz, DMSO- $\left.d_{6}\right) \delta 194.5$ (CO, ketone), $188.4(\mathrm{C}=\mathrm{O}$, benzoyl $), 175.8(\mathrm{C}=\mathrm{O}$, ester $), 171.6$ (C=O, acid), 168.5, 163.4, 161.6, 161.4, 143.7, 132.2, 131.2, 131.1, 124.8, 122.0, 118.9, 116.0, 114.4, 113.8, 113.4, 112.8, $112.0(\mathrm{C}=\mathrm{C}), 89.8(\mathrm{~N}-\mathrm{C}-\mathrm{OH}), 61.0\left(\mathrm{OCH}_{2} \mathrm{CH}_{3}\right), 56.0\left(\mathrm{OCH}_{3}\right), 55.7\left(\mathrm{OCH}_{3}\right), 40.6$ $\left(\mathrm{CH}_{2} \mathrm{COOMe}\right), 14.3\left(\mathrm{OCH}_{2} \underline{\mathrm{CH}_{3}}\right)$. HRMS: $\mathrm{m} / z(\mathrm{M}+\mathrm{H})$ calcd. for $\mathrm{C}_{30} \mathrm{H}_{27} \mathrm{NO}_{10}$ : 562.1708; found: 562.1684 .

4-(4-(ethoxycarbonyl)-2-hydroxy-2-(2-methoxy-2-oxoethyl)-5-(4-methoxyphenyl)-3-oxo-2,3-dihydro1H-pyrrol-1-yl)-2-hydroxybenzoic acid (7e): Color: light yellow, Yield 77\%, FTIR (ATR, $\mathrm{cm}^{-1}$ ): 3337 (br, OH), 3100-2848 (aromatic and alifatic $\mathrm{CH}$ ), 1737 (CO, ester), 1712 (CO, acid), 1701 (CO, benzoyl), 1659 (CO, pyrrole), 1611-1458 (C=C), $1253\left(\mathrm{O}_{-} \mathrm{CH}_{3}\right) .{ }^{1} \mathrm{H}$ NMR (400MHz, DMSO- $\left.d_{6}\right): \delta 7.52-6.23(\mathrm{~m}$, $7 \mathrm{H}, \mathrm{Ar}-\mathrm{H}) ; 3.94\left(\mathrm{q}, 2 \mathrm{H},{ }^{3} \mathrm{~J}_{\mathrm{H}-\mathrm{H}}=7.1 \mathrm{~Hz}, \mathrm{OCH}_{2} \mathrm{CH}_{3}\right), 3.72 ; 3.49(2 \mathrm{~s}, 6 \mathrm{H}, 2 \mathrm{MeO}) ; 2.94$ (the part A of the $\mathrm{AB}$ system, d, $1 \mathrm{H}, J_{\mathrm{gem}}=16.5, \mathrm{CH}_{2} \mathrm{COOMe}$ ), 2.55-DMSO- $d_{6}$ (the part B of the AB system, d, $1 \mathrm{H}$,

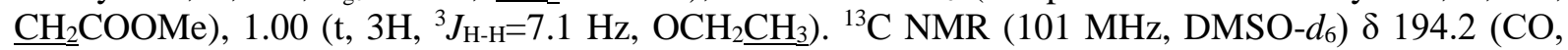
ketone), $178.2(\mathrm{C}=\mathrm{O}$, ester $), 171.4(\mathrm{C}=\mathrm{O}$, acid $), 168.8(\mathrm{C}=\mathrm{O}$, ester $), 163.1,163.0,161.1,139.9,131.0$, 130.5, 122.7, 118.7, 117.2, 116.5, 113.6, $101.4(\mathrm{C}=\mathrm{C}), 89.0(\mathrm{~N}-\mathrm{C}-\mathrm{OH}), 58.9\left(\mathrm{OCH}_{2} \mathrm{CH}_{3}\right), 55.6\left(\mathrm{OCH}_{3}\right)$, $52.0\left(\mathrm{OCH}_{3}\right)$, in DMSO- $d_{6}\left(\mathrm{CH}_{2} \mathrm{COOMe}\right), 14.5\left(\mathrm{OCH}_{2} \mathrm{CH}_{3}\right)$. HRMS: $\mathrm{m} / z(\mathrm{M}+\mathrm{Na})$ calcd. for $\mathrm{C}_{24} \mathrm{H}_{23} \mathrm{NO}_{10}$ : 508.1214; found: 508.1222. 
Table 1. Some properties of newly synthesized compounds 7<smiles>[R]C(=O)C1=C([R])O/C(=C/C(=O)O[Y19](C)C)C1=O</smiles><smiles>[R]C(=O)C1=C([R])N(c2ccc(Br)c(Br)c2)C(O)(CC(=O)O)C1=O</smiles>

\begin{tabular}{|c|c|c|c|c|c|c|}
\hline \multirow{2}{*}{ 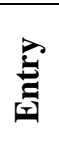 } & \multirow{2}{*}{ Ar-NH } & \multirow{2}{*}{$\begin{array}{l}\text { Mol. Formula } \\
\text { (Molecular } \\
\text { Weight) }\end{array}$} & \multirow{2}{*}{$\mathrm{MP}\left({ }^{\circ} \mathrm{C}\right)$} & \multirow{2}{*}{$\begin{array}{c}\text { Yields } \\
(\%)\end{array}$} & \multicolumn{2}{|c|}{$\begin{array}{c}\text { HRMS } \\
\text { m/z }\end{array}$} \\
\hline & & & & & Calc. & Found \\
\hline $7 \mathbf{a}$ & & $\begin{array}{l}\mathrm{C}_{29} \mathrm{H}_{25} \mathrm{NO}_{10} \\
(547.5160)\end{array}$ & $227-228$ & 74 & $\begin{array}{c}548.1551 \\
(M+H)\end{array}$ & $\begin{array}{c}548.1545 \\
(M+H)\end{array}$ \\
\hline $7 b$ & & $\begin{array}{l}\mathrm{C}_{30} \mathrm{H}_{27} \mathrm{NO}_{10} \\
(561.5430)\end{array}$ & $149-150$ & 80 & $\begin{array}{c}562.1708 \\
(M+H)\end{array}$ & $\begin{array}{c}562.1708 \\
(M+H)\end{array}$ \\
\hline $7 \mathrm{c}$ & & $\begin{array}{l}\mathrm{C}_{29} \mathrm{H}_{25} \mathrm{NO}_{10} \\
(547.5160)\end{array}$ & $186-187$ & 75 & $\begin{array}{c}548.1551 \\
(M+H)\end{array}$ & $\begin{array}{c}548.1533 \\
(M+H)\end{array}$ \\
\hline 7d & & $\begin{array}{l}\mathrm{C}_{30} \mathrm{H}_{27} \mathrm{NO}_{10} \\
(561.5430)\end{array}$ & $202-203$ & 83 & $\begin{array}{c}562.1708 \\
(M+H)\end{array}$ & $\begin{array}{c}562.1684 \\
(M+H)\end{array}$ \\
\hline $7 e$ & & $\begin{array}{c}\mathrm{C}_{24} \mathrm{H}_{23} \mathrm{NO}_{10} \\
(485.4450)\end{array}$ & $190-191$ & 77 & $\begin{array}{r}508.1214 \\
(M+N a)\end{array}$ & $\begin{array}{r}508.1222 \\
(M+N a)\end{array}$ \\
\hline
\end{tabular}

\subsection{Biological Studies}

\subsubsection{Allium Test}

Allium bulbs are obtained from local bazaar (Yozgat, Turkey) and germinated at room temperature. Root tips were then treated with $6.25,12.5,25,50$ and $100 \mu \mathrm{M}$ doses of 7a-e derivatives for a period of 24, 48 and 72 hours. Then, the root tips were placed in separate tubes and fixed in a 3:1 absolute alcohol: glacial acetic acid mixture, and kept overnight in the refrigerator. After fixation, root tips were stored in $70 \%$ alcohol in the refrigerator at $+4{ }^{\circ} \mathrm{C}$.

Determination of MI and CA was carried out in preparations made from 6 root tips for each periods and concentrations. For the preparation step, root tips were taken from $70 \%$ alcohol and hydrolyzed in $1 \mathrm{~N} \mathrm{HCl}$ solution at $60{ }^{\circ} \mathrm{C}$ for 8-10 minutes. After the hydrolysis process, the root tips were kept in distilled water twice for five minutes to dilute the effect of the acid. Then, root tips were stained with aceto-orsein for two hours and squashed in $45 \%$ acetic acid.

\subsubsection{Microscopic Evaluation and Statistical Analysis}

In determining the MI value, cells undergoing mitosis were counted in a total of 3000 cells for each concentration and control group. MI was calculated using the formula below:

$\mathrm{MI}=($ Number of cells undergoing mitosis $/$ Total number of cells $) \times 100$

A total of 3000 cells were analyzed for each concentration and control group to detect chromosomal defects. The percent CA was calculated with the following formula: 
Synthesis of novel hybrid compounds and their cytotoxic and genotoxic effetcs

$\mathrm{CA}=($ Total number of chromosomal defects $/$ Total number of cells $) \times 100$

Statistical analysis was performed by one-way analysis of variance (ANOVA) in MS-Excel software, and differences between groups were determined by Tukey test $(\mathrm{p}<0.05)$.

\section{Results and Discussion}

\subsection{Chemistry}

Synthesis of target compounds was carried out in three steps (Scheme 1). In the first step, 1,3bis(4-methoxyphenyl)propane-1,3-dione (1a) and ethyl 3-(4-methoxyphenyl)-3-oxopropanoate (1b) were used as 1,3-dicarbonyl compound. Compound 1a was synthesized in laboratory conditions and compound $\mathbf{1 b}$ was commercially available. By reacting 1,3-dicarbonyl compounds (1) with oxalyl chloride (2) reagent, furan-2,3-dione compounds (3) were synthesized in the first step and starting compounds were obtained. The reactions of compounds $\mathbf{3}$ with methyl (triphenylphosphoranylidene)acetate (4a) and (Carbetoxymethylene)triphenyl phosphorane (4b) reagents were carried out in benzene. As a result of the wittig reactions, furan-3-one compounds (5) were obtained. ${ }^{38}$ In the last step, hybrid salicylic acid-pyrrolone derivatives (7a-e), which are the target compounds (Scheme 1), were synthesized from the reactions of furan-3-one (5) compounds with 4aminosalicylic acid (6a) and 5-aminosalicylic acid reagents (6b) (Yields: 74-83\%). Some properties of synthesized compounds are given in Table 1.

In the synthesis step of the target compounds, the amino group (6) in the salicylic acid reagent makes nucleophilic attack on the carbon number five of the furan-3-one (5) compound. As a result of this attack, intra-ring nucleophilic addition of the unstable intermediate formed by the opening of the furanon ring takes place and the pyrrolone ring is formed. ${ }^{36}$ The opening of the furanon ring and the formation of the pyrrolone ring occur simultaneously. In the target compounds, the carbon atom to which the $\mathrm{OH}$ group (7) is attached is the chiral center. Methylene protons adjacent to this carbon atom are diastereotopic protons and give specific signals in NMR analysis. ${ }^{39}$

The 7a-d molecules of the target compounds contain four carbonyl groups in their structures. These are aroyl, ketone (pyrrole), ester and carboxylic acid groups, respectively. Compound 7e, unlike other compounds, does not contain an aroyl group. In compound 7a, FTIR bands belonging to the carbonyl groups in the ester, acid, benzoyl and pyrrole ring were observed at 1728, 1704, 1698 and 1679 $\mathrm{cm}^{-1}$, respectively. While the bands of stretching vibrations belonging to aromatic and aliphatic $\mathrm{C}=\mathrm{C}$ groups are observed between 1598-1444 $\mathrm{cm}^{-1}$, the bands of C-O stretching vibrations are characterized at $1251 \mathrm{~cm}^{-1}$. In the HNMR analysis of this compound, there is a signal of the $\mathrm{OH}$ proton in the carboxyl group at $11.36 \mathrm{ppm}$. In compound 7a, methoxy groups are substituted at positions 1 and 4 on the phenylene rings. Protons in the 1,4-disubstituted phenylene ring give the AA'BB' system in HNMR spectra. Doublet signals of $\mathrm{CH}$ protons $(\mathrm{H}-1, \mathrm{H}-2, \mathrm{H}-3, \mathrm{H} 4)$ in the ring were observed at $7.80\left({ }^{3} \mathrm{~J}_{\mathrm{H}-\mathrm{H}}=8.7\right.$ $\mathrm{Hz}, \mathrm{H}-1), 7.04\left({ }^{3} J_{\mathrm{H}-\mathrm{H}}=8.6 \mathrm{~Hz}, \mathrm{H}-3\right), 6.96\left({ }^{3} J_{\mathrm{H}-\mathrm{H}}=8.6 \mathrm{~Hz}, \mathrm{H}-4\right)$ and $6.83\left({ }^{3} J_{\mathrm{H}-\mathrm{H}}=8.7 \mathrm{~Hz}, \mathrm{H}-2\right) \mathrm{ppm}$ (Scheme 2). Signals of three aromatic hydrogen atoms in the salicylic acid group were observed as singlet signals at $7.55 \mathrm{ppm}$, doublet signals at $7.11\left({ }^{3} J_{\mathrm{H}-\mathrm{H}}=7.6 \mathrm{~Hz}\right)$ and $6.88 \mathrm{ppm}\left({ }^{3} J_{\mathrm{H}-\mathrm{H}}=8.8 \mathrm{~Hz}\right)($ Scheme 2$)$. The HNMR signals of three methoxy groups in this compound were observed as singlet at $3.83,3.69$ and $3.57 \mathrm{ppm}$. The methylene protons attached to the ester carbonyl in compound 7a give AB system in HNMR analysis due to the chiral of the neighboring carbon atom. ${ }^{39}$ The signals of methylene protons were seen as a doublet at $3.02 \mathrm{ppm}\left(J_{\mathrm{gem}}=16.3 \mathrm{~Hz}\right)$ and in the signal range of the DMSO- $d_{6}$ solvent. CNMR signals of twenty-five carbon atoms in compound 7a gave signals in the expected regions. Signals of ketone (pyrrole), benzoyl, ester and carboxylic acid groups were observed at 194.4, 188.3, 177.1 and 171.3 ppm, respectively, and aromatic $\mathrm{C}=\mathrm{C}$ groups signals between $169.2 \mathrm{ppm}$ and $111.4 \mathrm{ppm}$ were observed. 
Gümüş et al., Org. Commun. (2021) 14:3 280-293<smiles>[R]C(=O)CC(C)=O</smiles><smiles>[R]C(=O)C1=C([R3])OC(=O)C1=O</smiles><smiles>CCOC(=O)C(C)C</smiles><smiles>[R]C(=O)C=C1OC([R3])=C(C([R])=O)C1=O</smiles>

3

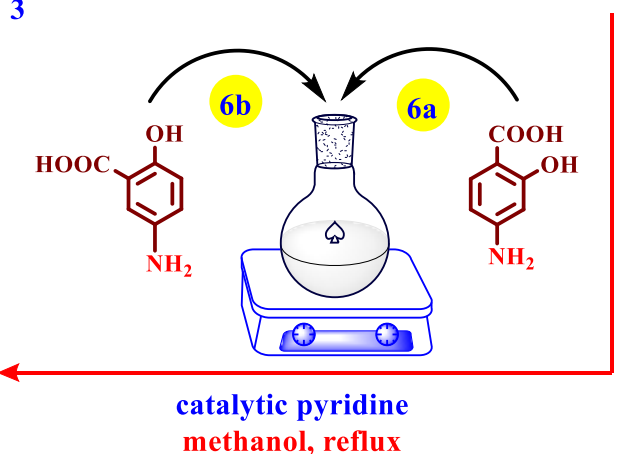<smiles>COc1ccc(C2=C(c3ccc(OC)cc3)N(CC(=O)O)C(CC=C(C)C)(Nc3ccc(O)c(C(=O)O)c3)C2=O)cc1</smiles>

$7 a$<smiles>[R1]C(=O)C1=C([R3])N(c2ccc([R1])c([13CH3])c2)C(C)(C(=O)OCC)C1=O</smiles><smiles>CCOC(=O)C1(O)C(=O)C2=C(c3ccc(OC)cc3)N(c3ccc(O)c(C(=O)O)c3)C(C)(O)C21</smiles>

$7 \mathbf{b}$

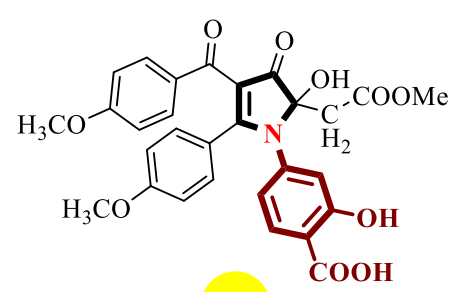

$7 \mathrm{c}$<smiles>CCOC(=O)CC1(C)C(=O)C(C(=O)c2ccc(OC)cc2)=C(c2ccc(OC)cc2)N1c1ccc(C(=O)O)c(O)c1</smiles>

7d<smiles>CCOC(=O)C1=C(c2ccc(OC)cc2)N(c2ccc(C(=O)O)c(O)c2)C(C)(C(C)=O)C1=O</smiles>

$7 \mathrm{e}$

Scheme 1. The synthesis of salicylic acid derivative hybrid compounds (7)

Signals of chiral carbon atom in the pyrrole ring, three methoxy and a methylene groups carbon resonated at 89,5 (N-C-OH), 55.9, 55.7 and $52.2\left(\mathrm{OCH}_{3}\right)$ and $40.1 \mathrm{ppm}\left(\mathrm{CH}_{2}\right)$, respectively. The target compounds contain asymmetric carbon atoms adjacent to methylene protons in their structures. Therefore, doublet signals observed in HNMR analyzes of these molecules are very specific for the characterization of structures. All signals of the methylene and methyl groups attached to the ester carbonyl in the target molecules and the methoxy groups attached to the aryl groups were observed as expected in the HNMR and CNMR analyzes. The HRMS analysis data of compound $7 \mathbf{a}(\mathrm{m} / \mathrm{z}, \mathrm{M}+\mathrm{H}$, calcd. for $\mathrm{C}_{29} \mathrm{H}_{25} \mathrm{NO}_{10}$ : 548.1551; found: 548.1545) are also in agreement with the molar mass. The spectral data of 7a and other compounds (7b-e) are largely similar. Due to the substituents attached to the ester carbonyl and the pyrrole ring, there are minor differences in FTIR and NMR analysis. Spectral findings of target molecules are compatible with their molecular structures, and NMR and HRMS spectra are given in the Suppporting information file. 
Synthesis of novel hybrid compounds and their cytotoxic and genotoxic effetcs
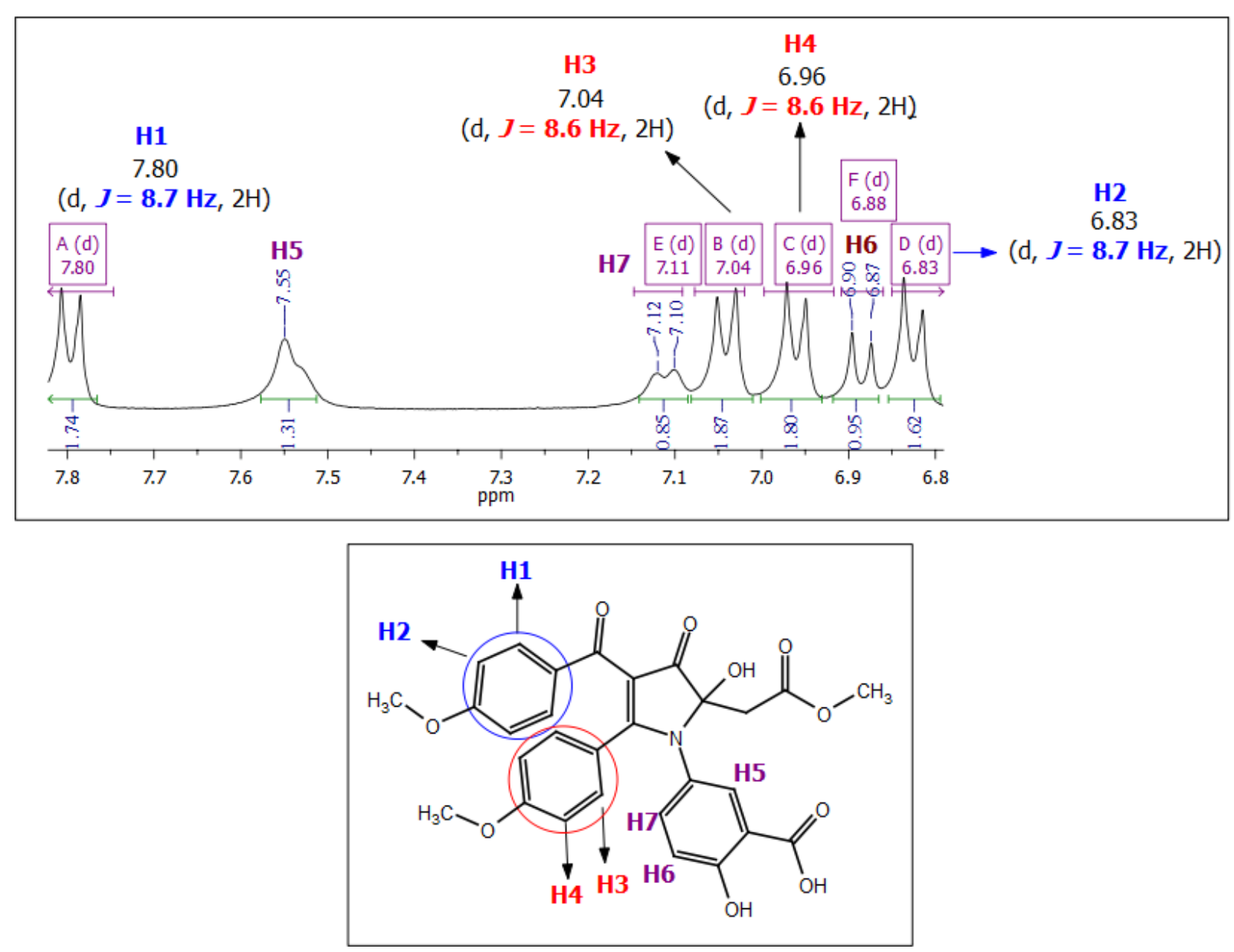

Scheme 2. NMR analysis of the aromatic protons in compound $\mathbf{7 a}$

\subsection{Cytotoxic and Genotoxic Data}

\subsubsection{Mitotic Index Data}

All concentrations and application times (excluding the 72-hour application of 7e) of salicylic acid derivatives decreased the mitotic index in A. cepa root tip cells compared to the control. These decreases are not statistically significant in the derivatives $\mathbf{7 b}$, 7d, and $\mathbf{7 e}$ (Table 2). On the contrary, these reductions are significant at 50 and $100 \mu \mathrm{M}$ in derivatives $7 \mathbf{a}$ (in all application times) and 7c (in only 24-hour application) and at $100 \mu \mathrm{M}$ in derivative 7c (in 48, 72-hours application) compared to control $(\mathrm{p}<0.05)$. Compounds $\mathbf{7 a}$ and $\mathbf{7 c}$ indicated cytotoxic potential with significant decreases over the control group at high concentrations. These derivatives produced a mitodepressive effect in A. cepa root tip cells. The cytotoxic effect from 7a and 7c may have caused serious damage to DNA and slowed down the transitions in the cell cycle. A decrease in MI is indicative of decreased cell proliferation. ${ }^{40} \mathrm{In}$ cells exposed to a toxic substance, cell cycle checkpoints prevent the transition from G1 to S phase or from G2 to mitosis, depending on the location of DNA damage in the cycle. Damage to DNA can also inhibit DNA synthesis and thus RNA and protein synthesis. In cells whose DNA is not replicated, the transition to the division phase is prevented by inactivation of kinase complexes. ${ }^{41}$ 
Gümüş et al., Org. Commun. (2021) 14:3 280-293

Table 2. Mitotic index results in Allium cepa root tip cells

\begin{tabular}{llllll}
\hline $\begin{array}{l}\text { Concentrations } \\
(\boldsymbol{\mu M})\end{array}$ & $\mathbf{7 a}$ & $\mathbf{7 b}$ & $\mathbf{7 c}$ & $\mathbf{7 d}$ & $\mathbf{7 e}$ \\
\hline Control & 8.30 & 6.90 & 6.90 & 8.18 & 7.03 \\
$6.25(24 \mathrm{~h})$ & 6.80 & 6.80 & 6.20 & 7.49 & 7.13 \\
$12.5(24 \mathrm{~h})$ & 6.27 & 6.57 & 4.43 & 7.09 & 6.37 \\
$25.0(24 \mathrm{~h})$ & 5.73 & 6.27 & 4.57 & 7.28 & 5.73 \\
$50.0(24 \mathrm{~h})$ & $3.37^{*}$ & 5.60 & $2.80^{*}$ & 7.47 & 6.83 \\
$100(24 \mathrm{~h})$ & $2.27^{*}$ & 5.30 & $2.70^{*}$ & 6.88 & 5.87 \\
\hline Control & 6.40 & 5.97 & 5.07 & 7.88 & 6.40 \\
$6.25(48 \mathrm{~h})$ & 5.67 & 5.20 & 3.40 & 6.39 & 5.87 \\
$12.5(48 \mathrm{~h})$ & 5.63 & 5.07 & 3.67 & 7.10 & 5.50 \\
$25.0(48 \mathrm{~h})$ & 4.27 & 4.70 & 3.20 & 7.51 & 5.33 \\
$50.0(48 \mathrm{~h})$ & $3.27^{*}$ & 4.50 & 3.03 & 6.02 & 5.53 \\
$100(48 \mathrm{~h})$ & $2.23^{*}$ & 4.23 & $1.80^{*}$ & 7.39 & 4.60 \\
\hline Control & 7.03 & 3.93 & 4.53 & 5.99 & 4.90 \\
$6.25(72 \mathrm{~h})$ & 5.73 & 3.07 & 4.00 & 5.62 & 4.93 \\
$12.5(72 \mathrm{~h})$ & 4.60 & 3.00 & 3.63 & 5.64 & 5.13 \\
$25.0(72 \mathrm{~h})$ & 4.00 & 3.10 & 3.67 & 5.73 & 4.90 \\
$50.0(72 \mathrm{~h})$ & $2.23^{*}$ & 2.93 & 2.03 & 5.69 & 4.77 \\
$100(72 \mathrm{~h})$ & $1.93^{*}$ & 2.90 & $0.67^{*}$ & 5.25 & 5.07 \\
\hline $\mathrm{p}<0.05$ & & & & &
\end{tabular}

\subsubsection{Chromosome Aberrations Data}

All concentrations of salicylic acid derivatives caused various abnormalities such as bridge, stickiness, c-mitosis, lagging, vagrant chromosome, binucleate cell, polar defect, and chromosome loss at mitotic stages at each application time. All concentrations of salicylic acid derivatives and all application times showed an increase in the frequency of chromosomal aberrations in A. cepa root tips compared to the control group (Table 3 ). These increases are not statistically significant in the derivative $\mathbf{7 b}$. In addition, CA rates are considerably higher than the control at high concentrations in $\mathbf{7 a}, \mathbf{7 c}$, and 7e excluding the 24-hour application of $7 \mathbf{e}(\mathrm{p}<0.05)$. Compound $7 \mathbf{d}$ indicated high genotoxic potential with significant increases over the control group at all concentrations and exposure times. The increase in CA frequency may have resulted from the disruption of DNA repair as a result of possible genotoxic derivatives inhibiting DNA polymerase activity. In addition, low concentrations may indirectly cause genotoxic effects and produce significant increases in the frequency of chromosomal aberrations. ${ }^{42}$ 
Synthesis of novel hybrid compounds and their cytotoxic and genotoxic effetcs

Table 3. Chromosome aberrations results in Allium cepa root tip cells

\begin{tabular}{llllll}
\hline Concentrations $(\boldsymbol{\mu M})$ & $\mathbf{7 a}$ & $\mathbf{7 b}$ & $\mathbf{7 c}$ & $\mathbf{7 d}$ & $\mathbf{7 e}$ \\
\hline Control & 1.07 & 1.73 & 1.53 & 1.99 & 2.73 \\
$6.25(24 \mathrm{~h})$ & 1.60 & 1.93 & 1.67 & $4.45^{*}$ & 3.70 \\
$12.5(24 \mathrm{~h})$ & 1.73 & 1.87 & 2.17 & $4.99^{*}$ & 3.87 \\
$25.0(24 \mathrm{~h})$ & 2.83 & 2.17 & 1.90 & $5.44^{*}$ & 3.60 \\
$50.0(24 \mathrm{~h})$ & $3.43^{*}$ & 2.13 & $3.57^{*}$ & $4.15^{*}$ & 3.80 \\
$100(24 \mathrm{~h})$ & $3.50^{*}$ & 2.87 & $4.53^{*}$ & $4.46^{*}$ & 3.70 \\
\hline Control & 1.13 & 1.67 & 1.67 & 1.29 & 2.57 \\
$6.25(48 \mathrm{~h})$ & 1.93 & 1.60 & 1.47 & $4.66^{*}$ & 3.27 \\
$12.5(48 \mathrm{~h})$ & 3.70 & 1.93 & 1.97 & $5.11^{*}$ & 3.10 \\
$25.0(48 \mathrm{~h})$ & 3.63 & 2.27 & 2.80 & $5.63^{*}$ & 3.43 \\
$50.0(48 \mathrm{~h})$ & $4.40^{*}$ & 2.17 & 3.50 & $5.60^{*}$ & $4.40^{*}$ \\
$100(48 \mathrm{~h})$ & $4.63^{*}$ & 3.20 & $4.57 *$ & $6.90^{*}$ & $4.40^{*}$ \\
\hline Control & 1.23 & 1.67 & 1.83 & 0.49 & 3.40 \\
$6.25(72 \mathrm{~h})$ & 1.47 & 1.83 & 2.17 & $3.33^{*}$ & 4.10 \\
$12.5(72 \mathrm{~h})$ & 2.43 & 1.73 & 2.13 & $3.55^{*}$ & 4.27 \\
$25.0(72 \mathrm{~h})$ & 4.00 & 2.00 & 3.17 & $4.80^{*}$ & 4.77 \\
$50.0(72 \mathrm{~h})$ & $5.13^{*}$ & 2.23 & 3.30 & $4.24^{*}$ & $5.13 *$ \\
$100(72 \mathrm{~h})$ & $5.53^{*}$ & 3.43 & $4.77^{*}$ & $5.45^{*}$ & $5.27 *$ \\
\hline$* \mathrm{p}<0.05$ & & & & &
\end{tabular}

\subsubsection{Cytotoxicity and Genotoxicity in Salicylic Acid-Pyrrole Hybrid Compounds}

In the present study, MI rates are lower than the control group, which may induce chromosomal defects. Especially low MI values at 50 and $100 \mu \mathrm{M}$ concentrations of derivatives 7a and 7c are statistically significant and indicate a possible cytotoxic potential. Chromosomal defects are an important parameter in detecting the potential genotoxic effects of chemical matters. ${ }^{43}$ The stickiness and c-mitosis among the observed chromosomal defects may have originated from the disrupted stages of mitosis because salicylic acid-pyrrolone hybrid compounds inhibit spindle fiber formation. In addition, c-mitosis and vagrant chromosomes can cause aneuploidy and bridge formations can cause chromosomal breaks. ${ }^{29}$ There is also a positive correlation between stickiness and anaphase bridges, and sticky chromosomes can remain attached to the bridges and exert a potent genotoxic effect, causing cell death. ${ }^{44}$

There are studies in the literature investigating the cytotoxic and genotoxic potentials of various salicylic acid derivatives. Giri et al. (1996) performed in vivo sister chromatid exchange (SCE) and CA assay for six salicylic acid derivatives in bone marrow cells of mice. In this study, six salicylic acid derivatives including acetyl salicylic acid (aspirin), salicylic acid, salicylamide, sodium salicylate, diflunisal and niclosamide were used. Diflunisal and niclosamide showed genotoxic effects in SCE and CA tests. Acetyl salicylic acid and sodium salicylate showed weak genotoxicity only at the highest concentration. ${ }^{45}$ Pawar et al. (2009) demonstrated the anti-genotoxic potential of acetylsalicylic acid and thiosalicylic acid with a reduction in comet parameters in bone marrow cells and micronucleated reticulocytes in peripheral blood. ${ }^{46}$ L5178Y mouse lymphoma cells were used to evaluate the 
Gümüş et al., Org. Commun. (2021) 14:3 280-293

genotoxicity of salicylic acid with and without metabolic activation, and concentrations up to 1400 $\mu \mathrm{g} / \mathrm{ml}$ were tested. Cyclophosphamide and methylmethanesulfonate were used as positive controls. Salicylic acid was not genotoxic effect with or without metabolic activation at the concentrations tested. ${ }^{47}$ The genotoxic potential of sodium salicylate was evaluated with Chinese hamster ovary cells to a concentration of $0.5 \mathrm{mM}$. Sodium salicylate has no genotoxic effect in the tested concentration range $(0.06$ to $0.5 \mathrm{mM})$, both with and without metabolic activation. ${ }^{48}$

\section{Conclusion}

Due to the diversity of biological activities, pyrrolone and salicylic acid compounds are used in many applications. The effects of these structures on living metabolism, development and treatment processes are particularly interesting. In this study, five compounds that can be potentially used in different industrial applications were synthesized and their cytotoxic and genotoxic effects were evaluated. The hybrid compounds (7a-e) containing pyrrolone and salicylic acid nuclei were synthesized by a three-step synthesis procedure. In the target compounds, methylene protons adjacent to chiral carbon atom are diastereotopic protons and give specific signals belonging to $A B$ system in NMR analysis. As a result, it has been determined that novel hybrid compounds have negative effects on cell cycle proliferation due to increasing concentrations and cause many and different types of chromosomal defects. Target molecules induced chromosomal defects such as bridge, stickiness, c-mitosis, anaphase lagging, vagrant chromosome, binucleate cell, polar defect and chromosome loss in Allium root tips. High concentrations of these derivatives may have possible cytotoxic (7a and $7 \mathbf{c})$ and genotoxic $(\mathbf{7 a}, \mathbf{7}$, $\mathbf{7 e}$, and especially $\mathbf{7 d}$ ) potential.

\section{Acknowledgements}

This work was financially supported by the Science and Technology Practice \& Research Centre of Yozgat Bozok University (Project No: 6602a-ASYO/19-341). The authors thank to the staff of this centre. Biological activities of this article was partly produced from MSc thesis of Selin CAN. Selin CAN would like to thank Nisa GÜMÜŞ for her guiding in the experiments.

\section{Supporting Information}

Supporting information accompanies this paper on http://www.acgpubs.org/journal/organiccommunications.

\section{ORCID}

Mehmet Gümüş: 0000-0001-9262-7940

Selin Can: 0000-0002-9083-0643

Halil Erhan Eroğlu: 0000-0002-4509-4712

İran Koca: 0000-0001-7873-159X

\section{References}

[1] Rainsford, K.D. Aspirin and Related Drugs, Taylor \& Francis Ltd., London, UK., 2004, 770 pp.

[2] Hedner, T.; Everts, B. The early clinical history of salicylates in rheumatology and pain. Clin. Rheumatol. 1998, 17(1), 17-25.

[3] Hauso, O.; Martinsen, T.C.; Waldum, H. 5-Aminosalicylic acid, a specific drug for ulcerative colitis. Scand. J. Gastroenterol. 2015, 50(8), 933-941.

[4] Omoteyama, K.; Sato, T.; Arito, M.; Sato, M.; Suematsu, N.; Kurokawa, M.S.; Kato, T. Effects of salazosulfapyridine on the profile of cell surface proteins, revealed by biotinylation of cell surface proteins and 2-dimensional electrophoresis. Biochim. Biophys. Acta Proteins Proteom. 2019, 1867(1), 47-56.

[5] Seferoğlu, B.; Altaş, E.U.; Şenel, K. Antimalarials and sulfasalazine, Turkiye Klinikler. J PM\&R-Special Top. 2014, 7(4), 20-24. 
Synthesis of novel hybrid compounds and their cytotoxic and genotoxic effetcs

[6] Yeonhwa, S.; Ran, S.H.; Jaewoo, J.; Tae-Hoon, S.; Mun, B.S.; Seung-Jae, M.; Mun, B.S.; Seung-Jae, M.; Jin-Sun, K.; Mo, K.K.; Seung-Jae, M.; Kyung, C. Sulfasalazine attenuates evading anticancer response of CD133-positive hepatocellular carcinoma cells. J. Exp. Clin. Cancer Res. 2017, 36(1), 38.

[7] Abdu-Allah, H.H.; El-Shorbagi, A.N.A.; Abdel-Moty, S.G.; El-Awady, R.; Abdel-Alim, A.A.M. 5Aminosalyclic acid (5-ASA): A unique anti-inflammatory salicylate. Med. Chem. 2016, 6(5), 361/1-361/10.

[8] Green, J.R; Lobo, A.J.; Holdsworth, C.D.; Leicester, R.J.; Gibson, J.A.; Kerr, G.D.; Hodgson, H.J.; Parkins, K.J.; Taylor, M.D. Balsalazide is more effective and better tolerated than mesalamine in the treatment of acute ulcerative colitis. The Abacus Investigator Group, Gastroenterology 1998, 114(1), 15-22.

[9] Ibrahim, M.A.; Elagawany, M.; Ibrahim, T.S. Green and catalyst-free synthesis of olsalazine analogs. Green Chem. Lett. Rev. 2016, 9(2), 91-95.

[10] Pozharskii, A.K.; Ramsden, C.; Joule, J.; Zhdankin, V. Handbook of Heterocyclic Chemistry 2nd Edition, United Kingdom, Elsevier Science \& Technology, 2000, 520 pp.

[11] Gholap, S.S. Pyrrole: An emerging scaffold for construction of valuable therapeutic agents. Eur. J. Med. Chem. 2016, 110, 13-31.

[12] Snyder, R.D.; Green, J.W. A review of the genotoxicity of marketed pharmaceuticals. Mutat. Res. 2001, 488(2), 151-69.

[13] Ali, Y.; Alam, M.S.; Hamid, H.; Hussain, A. 2(3H)Pyrrolone-a biologically active scaffold. Oriental J Chem. 2014, 30(1), 1-16.

[14] Mohamed, M.S.; El-Domany, R.A.; Abd El-Hameed, R.H. Synthesis of certain pyrrole derivatives as antimicrobial agents. Acta. Pharm. 2009, 59(2), 145-158.

[15] Alam, M.M.; Husain, A.; Hasan, S.M.; Suruchi; Answer, T. Synthesis and pharmacological evaluation of $2(3 \mathrm{H})$-Furanones and 2(3H)-Pyrrolones, combining analgesic and anti-inflammatory properties with reduced gastrointestinal toxicity and lipid peroxidation. Eur. J. Med. Chem. 2009, 44(6), 2636-2642.

[16] Husain, A.; Alam, M.M.; Siddiqui, N. Synthesis, reactions and biological activity of 3-arylidene-5-(4methylphenyl)-2 (3H)-furanones. J. Serbian Chem. Soc. 2009, 74(2), 103-115.

[17] Husain, A.; Alam, M.M.; Hasan, S.M.; Yar, M.S. 2(3H)-furanones and 2(3H)-pyrrolones: synthesis and antimycobacterial evaluation. Acta Pol. Pharm. 2009, 66(2), 173-180.

[18] Murugesan, D.; Mital, A.; Kaiser, M.; Shackleford, D.M.; Morizzi, J.; Katneni, K.; Campbell, M.; Hudson, A.; Charman, S.A.; Yeates, C.; Gilbert, I.H. Discovery and structure-activity relationships of pyrrolone antimalarials. J. Med. Chem. 2013, 56(7), 2975-2990.

[19] Murugesan, D.; Kaiser, M.; White, K.L.; Norval, S.; Riley, J.; Wyatt, P.G.; Charman, S.A.; Read, K.D.; Yeates, C.; Gilbert, I.H. Structure-activity relationship studies of pyrrolone antimalarial agents. ChemMedChem. 2013, 8(9), 1537-1544.

[20] Smith, A.B.; Charnley, A.K.; Hirschmann, R. Pyrrolinone-based peptidomimetics."Let the enzyme or receptor be the judge". Acc. Chem. Res. 2011, 44(3), 180-193.

[21] Bassetto, M.; Leyssen, P.; Neyts, J.; Yerukhimovich, M.M.; Frick, D.N.; Brancale, A. Shape-based virtual screening, synthesis and evaluation of novel pyrrolone derivatives as antiviral agents against HCV. Bioorg. Med. Chem. Lett. 2017, 27(4), 936-940.

[22] Erden, I.; Ozer, G.; Hoarau, C.; Cao, W. Cyclocondensation of amidines with dimethyl acetylenedicarboxylate: a convenient entry into tetramic acids. J. Heterocycl. Chem. 2006, 43(2), 395-399.

[23] Zhang, Z.J.; Ren, Z.H.; Wang, Y.Y.; Guan, Z.H. Cu(TFA)2-catalyzed oxidative tandem cyclization/1,2alkyl migration of enamino amides for synthesis of pyrrolin-4-ones. Org. Lett. 2013, 15(18), 4822-4825.

[24] Huang, J.; Liang, Y.; Pan, W.; Yang, Y.; Dong, D. Efficient synthesis of highly substituted pyrrolin-4-ones via PIFA-mediated cyclization reactions of enaminones. Org. Lett. 2007, 9(26), 5345-5348.

[25] Gouault, N.; Le Roch, M.; Cornee, C.; David, M.; Uriac, P. Synthesis of substituted pyrrolin-4-ones from amino acids in mild conditions via a gold-catalyzed approach. J. Org. Chem. 2009, 74(15), 5614-5617.

[26] Spina, R.; Colacino, E.; Gabriele, B.; Salerno, G.; Martinez, J.; Lamaty, F. Synthesis of pyrrolin-4-ones by Pt-catalyzed cycloisomerization in PEG under microwaves. J. Org. Chem. 2013, 78(6), 2698-2702.

[27] Qiu, Y.F.; Yang, F.; Qiu, Z.H.; Zhong, M.J.; Wang, L.J.; Ye, Y.Y.; Song, B.; Liang, Y.M. Bronsted acid catalyzed and NIS-promoted cyclization of diynones: selective synthesis of 4-Pyrone, 4-Pyridone, and 3Pyrrolone derivatives. J. Org. Chem. 2013, 78(23), 12018-12028.

[28] Fiskesjö, G. The Allium test as standart in enviromental monitoring. Hereditas. 1985, 102, 99-112.

[29] Leme, D.M.; Marin-Morales, M.A. Allium cepa test in environmental monitoring: a review on its application. Mutat. Res. 2009, 682, 71-81.

[30] El-Shabhaby, O.A.; Abdel Migid, H.M.; Soliman, M.I.; Mashaly, I.A. Genotoxicity screening of industrial wastewater using the Allium cepa chromosome aberration assay. Pak. J. Biol. Sci. 2003, 6, $23-28$.

[31] Kovalchuk, O.; Kovalchuk, I.; Arkhipov, A.; Telyuk, P.; Hohn, B.; Kovalchuk, L. The Allium cepa chromosome aberration test reliably measures genotoxicity of soils of inhabited areas in the Ukraine contaminated by the Chernobyl accident. Mutat. Res. 1998, 415, 47-57. 
Gümüş et al., Org. Commun. (2021) 14:3 280-293

[32] Gümüş, M.; Gümüş, N.; Eroğlu, H.E.; Koca, İ. Design, synthesis and cytotoxic activities of pyrazoleperimidine hybrids. ChemistrySelect. 2020, 5(20), 5916-5921.

[33] Liman, R.; Ciğerci, I.H; Öztürk, N.S. Determination of genotoxic effects of Imazethapyr herbicide in Allium cep root cells by mitotic activity, chromosome aberration, and comet assay. Pestic. Biochem. Phys. 2015, 118, 38-42.

[34] Saripinar, E.; Guzel, Y; Onal, Z.; Ilhan, I.O.; Akcamur, Y. 4-(4-Methoxybenzoyl)-5-(4-methoxyphenyl)2,3-dihydro-2,3-furandione, its synthesis, thermolysis and Diels-Alder reactions with Schiff bases: experimental data and calculations. J. Chem. Soc. Pak. 2000, 22, 308-317.

[35] Saalfrank, R.W.; Lutz, T.; Hoerner, B.; Guendel, J.; Peters, K.; Von Schnering, H.G. 2,3-Dioxo-2,3dihydrofurane, 2 Vielseitige Synthese von 2,3-Dioxo-2,3-dihydrofuranen und Alkylidenbutenoliden.kristall- und molekülstruktur von 5-(4-Chlorphenyl)-4-methoxycarbonyl-2,3-dioxo-2,3-dihydrofuran. Chem. Ber. 1991, 124(10), 2289-95.

[36] Ungoren, S.H.; Sacmaci, M.; Akcamur, Y.; Arici, C.; Ulku, D. Synthesis of new 2,3-dihydrofuran-3-one derivative and its reactions with some primary amines. J. Heterocycl. Chem. 2004, 4l(2), 151-155.

[37] Sacmaci, M.; Bolukbasi, H.; Sahin, E. Reactions of some furan-3-ones with 2,3-diaminopyridine and its derivatives. Bull. Korean Chem. Soc. 2012, 33(1), 90-94.

[38] Koca, İ.; Sacmaci, M.; Yilmaz, F.; Üngören, S.H. Synthesis and structural characterization of Pyrrole heterocyclic systems bearing amino acid units: novel Pyrrol-3-ones, Pyrrolo[1,2-a][3,1]benzoxazines, and Pyrrolo[2,1-b][1,3]oxazoles. J. Heterocycl. Chem. 2014, 51(1), 212-218.

[39] Gümüş, M.; Dişli, A.; Yakan, M.; Yiğitcan' S.; Koca, İ. One-pot and multi-step syntheses of new 2-(4,5dihydro-1H-pyrazol-1-yl) thiazole derivatives. Org. Commun. 2018, 112, 98-110.

[40] Webster, P.L.; Davidson, D. Changes in the duration of the mitotic cycle induced by colchicine and indol3-yl-acetic acid in Vicia faba roots. J. Exp. Bot. 1969, 20(3), 671-685.

[41] Vermeulen, K.; Van Bockstaele, D.R.; Berneman, Z.N. The cell cycle: a review of regulation, deregulation and therapeutic targets in cancer. Cell Prolif. 2003, 36(3), 131-149.

[42] Vodicka, P.; Kumar, R.; Stetina, R.; Sanyal, S.; Soucek, P.; Haufroid, V.; Maria Dusinska, M.; Kuricova, M.; Zamecnikova, M.; Musak, L.; Buchancova, J.; Norppa, H.; Hirvonen, A.; Vodickova, L.; Naccarati, A.; Matousu Z.; Hemminki, K. Genetic polymorphisms in DNA repair genes and possible links with DNA repair rates, chromosomal aberrations and single-strand breaks in DNA. Carcinogenesis 2004, 25(5), 757 763.

[43] Ping, K.Y.; Darah, I.; Yusuf, U.K.; Yeng, C.; Sasidharan, S. Genotoxicity of Euphorbia hirta: an Allium cepa assay. Molecules 2012, 17, 7782-7791.

[44] Kabarity, A.; El-Bayoumi, A.; Habib, A. Effect of morphine sulphate on mitosis of Allium cepa root tips. Biol. Plant. 1974, 16, 275-282.

[45] Giri, A.K; Adhikari, N.; Khan, K.A. Comparative genotoxicity of six salicylic acid derivatives in bone marrow cells of mice. Mutat. Res. 1996, 370, 1-9.

[46] Pawar, A.A.; Vikram, A.; Tripathi, D.N.; Padmanabhan, S.; Ramarao, P.; Jena, G. Modulation of mitomycin C- induced genotoxicity by acetyl- and thio- analogues of salicylic acid. In Vivo. 2009, 23(2), 303-308.

[47] European Chemicals Agency (ECHA), Registration, Evaluation, Authorization, and Restriction of Chemical Substances (REACH) Dossier, Methyl Salicylate, https://echa.europa.eu/registration-dossier//registered-dossier/2227.

[48] European Chemicals Agency (ECHA), Registration, Evaluation, Authorization, and Restriction of Chemical Substances (REACH) Dossier, Sodium Salicylate, https://echa.europa.eu/registration-dossier//registered-dossier/13593.

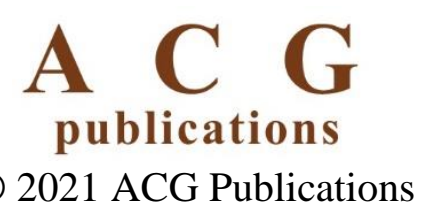

